\title{
Immunoglobulin G response and performance in Holstein calves supplemented with garlic powder and probiotics
}

\author{
T.W. Kekana ${ }^{1 \#}$, V.F. Nherera-Chokuda ${ }^{2}$, J.J. Baloyi ${ }^{3} \&$ C.M. Muya ${ }^{4}$ \\ ${ }^{1}$ Western Cape Department of Agriculture, SAET, P.O. Box 313, Oudtshoorn, 6625, South Africa \\ ${ }^{2}$ NERPO, 160 Garsfontein, Pretoria. 0081, South Africa \\ ${ }^{3}$ School of Agriculture, University of Venda, P/Bag X5050, Thohoyandou, 0950, South Africa \\ ${ }^{4}$ Agriculture Research Council-Animal Production, P/Bag X 02, Irene, 0062, South Africa
}

(Received 18 June 2019; Accepted 26 January 2020; First published online 25 April 2020)

\begin{abstract}
Copyright resides with the authors in terms of the Creative Commons Attribution 4.0 South African License.
See: http://creativecommons.org/licenses/by/4.0/za

Condition of use: The user may copy, distribute, transmit and adapt the work, but must recognize the authors and the South African Journal of Animal Science.
\end{abstract}

\begin{abstract}
The study evaluated the effects of garlic, probiotics, and in combination on levels of immunoglobulin $G$ (IgG) and growth performance in new-born Holstein calves. Thirty-two Holstein calves were randomly allocated to treatments at four days old and were maintained on them until they were 42 days old. The treatments consisted of control (C), garlic powder at $5 \mathrm{~g} /$ calf/day (GA), probiotics at $4 \mathrm{~g} /$ calf/day (PB), and the combination of garlic and probiotics (GP). Bodyweight, body length and heart girth measurements were taken to determine growth and blood was drawn to determine glucose and IgG. Faecal score and body temperature were recorded daily. Calves in GA and GP had higher IgG levels than calves in C and PB (28.0 $\mathrm{g} / \mathrm{L}$ and $27.5 \mathrm{~g} / \mathrm{L}$ versus $23.5 \mathrm{~g} / \mathrm{L}$ and $25.5 \mathrm{~g} / \mathrm{L}$, respectively). Calves in GP and PB groups had lower faecal scores than $C$ and GA (2.1 and 2.1 versus 2.3 and 2.2, respectively). Supplementation of GA, PB, and in combination did not affect feed intake and growth performance negatively, but improved serum IgG levels. Higher serum IgG in GP may indicate an improved intake and utilisation of nutrients that are responsible for immunity modulation and regulation. Probiotics and their combinations with garlic have the potential to reduce the incidence of diarrhoea when fed to young calves.
\end{abstract}

Keywords: dairy neonates, direct-fed microbes, natural herb

\#Corresponding author: ThapeloK@elsenburg.com

\section{Introduction}

The cost of rearing replacement heifers is high, representing a quarter of dairy farm expenses (Drackley et al., 2004). Reducing exposure to pathogens, improving immunity, and applying chemotherapeutic agents are focus areas in calf and heifer management (Earley \& Fallon, 1999). Calves have little or no immunity at birth, and colostrum is a crucial source of immunoglobulins for initiating innate defence systems (Lawrence \& Pierce, 1983; Piccone et al., 2009). However, early establishment of innate immunity in confined dairy calf management systems is often associated with failure of availability of colostrum and a low rate of intestinal absorption of IgG (Godden, 2008; Piccone et al., 2009). Antibiotics are vital in pathogen control. However, concerns about antibiotic residues in animal-sourced feeds and pathogen resistance are increasing, and alternative eco-friendly strategies are needed (Calsamiglia et al., 2000).

Probiotics alone are safe and effective feed additives that affect the performance of calves favourably and are highly recommended as an alternative to antibiotics (Zhang et al., 2015; Zhong et al., 2019). However, in semi-intensive feeding systems, the use of supplemental micro-nutrients, antibiotics, and even probiotics is limited.

Natural herbs enhance performance and health in dairy cattle and could serve as alternatives to both antibiotics and probiotics (Kekana et al., 2019; Seifzadeh et al., 2019). Supplementation with garlic (Allium sativum) enhances detoxification and restores physical strength and resilience (Amagase et al., 2001; Calsamiglia et al., 2000). The anti-parasitic, insecticidal, anti-oxidant, anti-inflammatory, bactericidal and hypoglycaemic characteristics of garlic result from allicin, an active secondary metabolite (Ghosh et al., 2010). Allicin is formed catalytically when garlic cloves are crushed and the enzyme alliinase of the bundle 
sheath cells mixes with its substrate, alliin, which is released from mesophyll cells (Lawson, 1996). Many commercial garlic preparations are available, including garlic powder. Garlic powder is a preparation of sliced, dried, and pulverized garlic cloves, which forms allicin when added to water or milk (Lawson, 1996).

Church (1976) and Busquet et al. (2005) postulated that direct-fed microbes and secondary metabolites of plants have similar effects on rumen development. Novak et al. (2012) reported that when combined with other supplements, direct-fed microbials could synergistically affect the immunity of calves. Mixtures of herbs, including garlic powder, combined with probiotics have improved blood glucose, beta hydroxyl butyrate and total serum proteins in dairy calves (Seifzadeh et al., 2019). Therefore, this study aimed to investigate IgG response and growth of pre-weaned Holstein calves supplemented with probiotics, garlic powder, and in combination.

\section{Materials and Methods}

The experiment was conducted at the Agricultural Research Council-Animal Production Institute

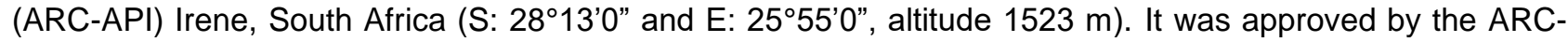
API Ethics Committee (APIEC 12/008).

Thirty-two healthy new-born Holstein calves $(36.2 \pm 4.5 \mathrm{~kg})$ were separated from their dam, after parturition and cleaning, and taken to the calf unit, where they received colostrum $(2 \mathrm{~L}$ at $09 \mathrm{~h} 00$ and $2 \mathrm{~L}$ at 14h00) for three days. All colostrum was tested with a colostrometer ${ }^{\mathrm{TM}}$ (Biogenics, Napa, Calif, USA), which indicated that it was of high quality. On day 4, the calves were stratified by birth weight and randomly allocated to one of four treatments (two males and six females per treatment). The treatments consisted of i) no additives (C); ii) $5 \mathrm{~g} / \mathrm{calf} / \mathrm{d} / \mathrm{garlic}$ powder (GA), iii) $4 \mathrm{~g} /$ calf/d/probiotic (PB), and iv) $5 \mathrm{~g} / \mathrm{calf} / \mathrm{d} / \mathrm{garlic}$ powder $+4 \mathrm{~g} /$ calf/d/probiotics (GP). One half of each treatment dosage was fed at each of two daily feedings of milk (9h00 and 14h00) from day 4 until day 35. From days 4 to 7 the calves were fed $2 \mathrm{~L}$ of whole milk (3. $23 \%$ $\mathrm{CP}, 3.47 \%$ fat, and $4.69 \%$ lactose) at $08 \mathrm{~h} 00$ and $14 \mathrm{~h} 00$. From days 8 to 35 , the calves were fed $3 \mathrm{~L}$ of milk at $8 \mathrm{~h} 00$ and another $3 \mathrm{~L}$ at $14 \mathrm{~h} 00$. From days 36 to 42 the calves were fed $4 \mathrm{~L}$ of milk at $08 \mathrm{~h} 00$, only.

The probiotic used contained Lactobacillus bavaricus, Lactobacillus casei, Lactobacillus rhamnosus, Lactobacillus coryniformis, Lactobacillus curvatus, Lactobacillus sake, Streptococcus species and Leuconostoc species with a total viable count of $1.3 \times 10^{7} \mathrm{cfu} / \mathrm{g}$. It was fed according to the manufacturer's guidelines $(4 \mathrm{~g} / \mathrm{calf} / \mathrm{d})$. Garlic powder was purchased from Deli Spice (Cape Town, South Africa). According to the company, the cloves of $A$. sativum were dried under shade and made into coarse powder $(0.4 \mathrm{~mm})$, which contained $3.9 \mathrm{~g} / 100 \mathrm{~g}$ moisture, $19.5 \mathrm{~g} / 100 \mathrm{~g}$ protein, $0.53 \mathrm{~g} / 100 \mathrm{~g}$ fat, ash of $3.4 \mathrm{~g} / 100 \mathrm{~g}, 1.1 \mathrm{mg} / 100$ $\mathrm{g}$ zinc, $12.5 \mathrm{mg} / 100 \mathrm{~g}$ selenium, $40.8 \mathrm{mg} / 100 \mathrm{~g}$ vitamin $\mathrm{C}$, and $7.6 \mathrm{mg} / 100 \mathrm{~g}$ vitamin $\mathrm{E}$. The main active ingredient of this powder was allicin (an organo-sulfur compound) at $1.5 \mathrm{mg} / 100 \mathrm{~g}$ dry matter (DM). A recommended garlic dosage level for dairy calves was not found, and thus the garlic dose in the current study was extrapolated from the recommended dose for human consumption, which is $6.5 \mathrm{~g}$ for a person weighing $65 \mathrm{~kg}$ (O'Gara et al., 2000).

Commercial calf starter consisted of $91.2 \% \mathrm{DM}, 17.5 \%$ crude protein (CP), $18.75 \%$ neutral detergent fibre (NDF), $8.69 \%$ acid detergent fibre (ADF), $0.65 \%$ calcium (C), $0.44 \%(P), 1.17 \%$ potassium (K), $0.22 \%$ magnesium (Mg), $250.16 \mathrm{ppm}$ iron ( $\mathrm{Fe}), 46.08 \mathrm{ppm}$ manganese $(\mathrm{Mn})$, and $10.28 \mathrm{ppm}$ copper $(\mathrm{Cu})$. (Meadow Feeds, Randfontein, South Africa, registration no. V 12012) and fresh water were available ad libitum from days 4 to 42 . The calves were housed individually in $15 \mathrm{~m}^{2}$ pens throughout the trial. Every pen had a plaited rubber matt and grass hay on the concrete floor as bedding. Daily intake of the starter, milk and water were measured throughout the experiment to determine feed conversion ratio (FCR). Bodyweight (BW), heart girth ( $\mathrm{HG})$, and body length (BL) were measured weekly. Heart girth was defined as the circumference of the thoracic cavity immediately behind the fore limbs and $B L$ was the distance from point of the shoulder to the point of tuber ischia (Ugur, 2005). The faecal scoring system used a 4-point scale (Larson et al., 1977). Faeces were scored and body temperature was measured daily. On days 2, 12, 22, 32 , and 42 , blood samples were collected from the jugular vein using vacutainer tubes that contained lithium heparin. The blood samples were centrifuged at $2500 \mathrm{rpm}$ until the serum was separated from the cellular constituents, after which the serum was stored at $-20^{\circ} \mathrm{C}$ pending analysis. The levels of IgG in serum were analysed as described by Morrill and Howard (2012). Glucose was determined using the Accu-Chek Easy (ACE) method (Rumsey et al., 1999).

Intake, measures of growth, serum IgG and glucose, body temperature and faecal score was analysed as repeated measures using the PROC MIXED model (SAS Institute Inc., Cary, North Carolina, USA). The daily observations were pooled by week before being analysed. The statistical model included treatment as a fixed effect, calf within treatment as a random effect, and time and its interaction with treatment as additional fixed effects. Time was modelled as a first-order autoregressive effect. Dry matter intake of starter $(\mathrm{g} / \mathrm{kg}$ of bodyweight), average daily gain (ADG), initial and final BW, and days and frequency of diarrhoea were 
subjected to ANOVA using PROC GLM (SAS Institute Inc., Cary, North Carolina, USA). Significance was declared at $P<0.05$ and tendencies were considered to exist at $0.05<P<0.10$.

\section{Results and Discussion}

Dry matter intake of starter ranged from $0.22 \mathrm{~kg} / \mathrm{d}$ for control calves to $0.27 \mathrm{~kg} / \mathrm{d}$ for calves fed GP, but did not differ among treatment groups. However, calves fed GP tended to consume more $(P<0.10)$ starter $(\mathrm{kg} / \mathrm{d}$ and $\mathrm{kg} / \mathrm{kg}$ of BW) and water compared with those supplemented with $\mathrm{C}$ and GA (Table 1). Additives did not affect energy intake. However, there were effects $(P<0.001)$ of week and interaction between treatment and week for DMI of starter (Table 1). When DMI of starter was evaluated weekly, differences occurred during the last week of the trial, in which supplemented calves consumed more starter $(\mathrm{kg} / \mathrm{d})$ than control calves (Figure 1). Average water intake and FCR were not affected by treatment. However, calves did consume more water and starter as they grew $(P=0.01)$. Consumption of feed, milk, and water, and growth performance are presented in Table 1.

Table 1 Starter, milk and water intake, and growth performance of Holstein calves as affected by garlic and probiotics supplementation

\begin{tabular}{|c|c|c|c|c|c|c|c|c|}
\hline \multirow{2}{*}{ Parameters } & \multicolumn{4}{|c|}{ Treatment } & \multirow{2}{*}{ SEM } & \multicolumn{3}{|c|}{$P$-value } \\
\hline & $\mathrm{C}$ & GA & PB & GP & & $\mathrm{T}$ & Week & T x Week \\
\hline \multicolumn{9}{|l|}{ Feed intake } \\
\hline Starter DMI (kg/day) & 0.22 & 0.23 & 0.25 & 0.27 & 0.02 & 0.17 & $<0.001$ & 0.01 \\
\hline Starter DMI ( $\mathrm{g} / \mathrm{kg}$ of BW) & 4.8 & 4.9 & 5.2 & 5.6 & 0.42 & 0.09 & - & - \\
\hline Milk intake (I/day) & 5.00 & 5.23 & 5.43 & 5.23 & 0.58 & 0.76 & 0.54 & 0.85 \\
\hline Water intake (I/day) & 2.4 & 2.45 & 2.24 & 2.48 & 0.18 & 0.74 & 0.01 & 0.12 \\
\hline ME intake (MJ/day) & 95.0 & 95.2 & 95.6 & 95.9 & 0.32 & 0.19 & $<0.001$ & 0.02 \\
\hline FCR & 0.52 & 0.48 & 0.32 & 0.27 & 0.11 & 0.22 & 0.006 & 0.51 \\
\hline \multicolumn{9}{|l|}{ Growth performance } \\
\hline Initial BW (kg) & 35.6 & 37.1 & 37.4 & 36.8 & 1.82 & 0.09 & - & - \\
\hline Final BW(kg) & 56.0 & 56.6 & 59.0 & 60.3 & 1.33 & 0.34 & - & - \\
\hline ADG $(\mathrm{kg})$ & 0.48 & 0.46 & 0.57 & 0.53 & 0.05 & 0.41 & - & - \\
\hline Body length $(\mathrm{cm})$ & 72.7 & 72.6 & 72.9 & 72.3 & 0.92 & 0.67 & 0.04 & 0.54 \\
\hline Heart girth $(\mathrm{cm})$ & 84.3 & 84.0 & 83.9 & 84.1 & 0.57 & 0.72 & 0.04 & 0.61 \\
\hline
\end{tabular}

C: control, GA: garlic, PB: probiotics, GP: garlic + probiotics, SEM: standard error of means. DMI: dry matter intake, ME: metabolizable energy, FCR: feed conversion ratio, ADG: average daily intake, BW: bodyweight

Average and weekly growth parameters (Table 1 and Figure 1) were not affected by the treatments $(P$ $>0.05)$. However, there were notable effects of week $(P=0.04)$ on $\mathrm{BL}$ and $\mathrm{HG}$. On average, serum $\operatorname{lgG}$ increased $(P<0.05)$ with supplemented groups, in which the GA and GP groups were the higher than PB. 

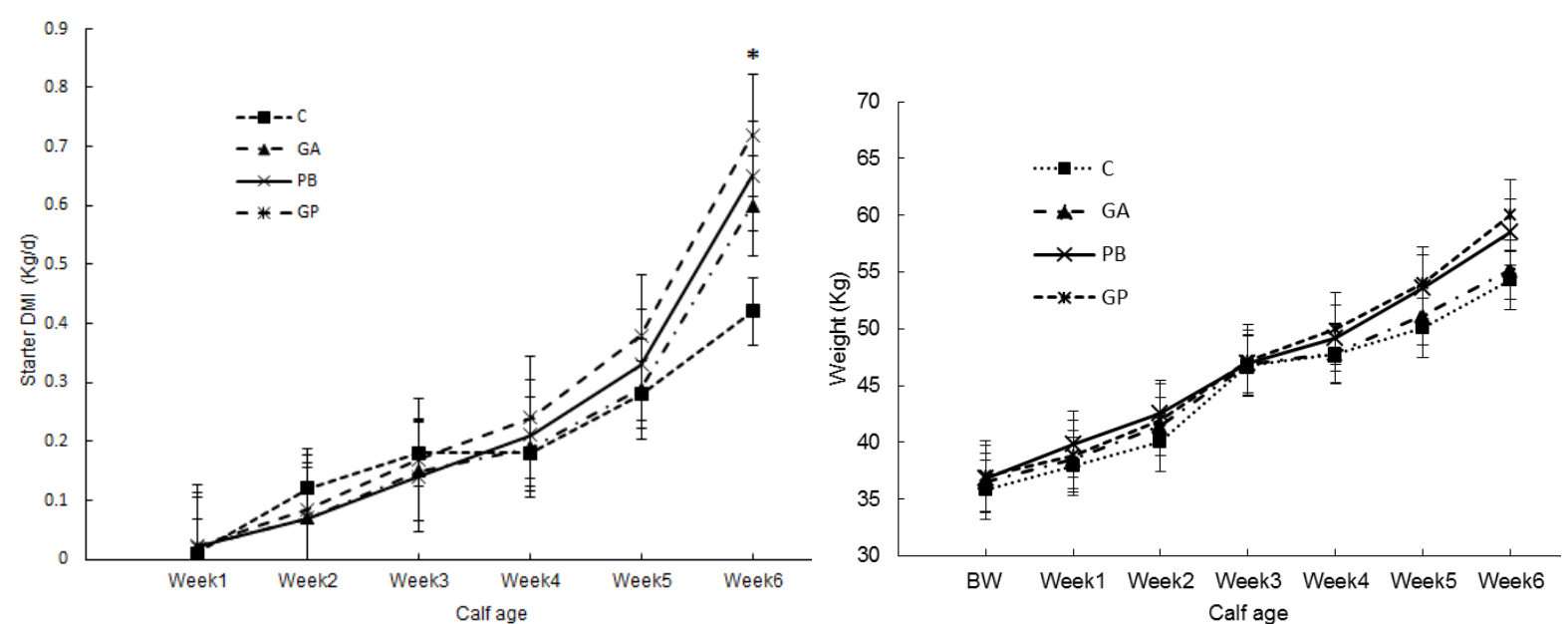

Figure 1 Starter dry matter intake and average weight of the calves fed control, garlic, probiotics and in combination over 42 days

GA: garlic; PB: probiotics; $G+P$ : garlic plus probiotics

Starter DMI for $\mathrm{C}$ at week 5 was lower than the rest of the treatments $(P<0.05)$

When evaluated weekly, the IgG levels increased with the age of the calves (Table 2). Group GA did not differ from GP, but both were higher $(P<0.05)$ than $C$ and PB. Calves fed GA treatment tended $(P=0.09)$ to increase blood glucose with significant week effect. Faecal score in Group P did not differ from GP, but both were higher than $C$, whereas there was no difference between $C$ and GA. Diarrhoea frequency tended to be higher in $\mathrm{C}(P=0.07)$.

Table 2 Serum IgG, glucose levels, body temperature and diarrhoeal incidence of Holstein calves as affected by garlic and probiotics supplementation

\begin{tabular}{|c|c|c|c|c|c|c|c|c|}
\hline \multirow{2}{*}{ Parameters } & \multicolumn{4}{|c|}{ Treatment } & \multirow{2}{*}{ SEM } & \multicolumn{3}{|c|}{$P$-value } \\
\hline & $\mathrm{C}$ & $\mathrm{GA}$ & PB & GP & & $\mathrm{T}$ & Week & T $x$ Week \\
\hline Average serum $\lg G(g / l)$ & $23.5^{c}$ & $28.0^{a}$ & $25.5^{\mathrm{b}}$ & $27.5^{a}$ & 0.48 & 0.02 & $<0.001$ & $<0.001$ \\
\hline Day 02 & 12.3 & 12.4 & 13.8 & 11.5 & 1.08 & 0.36 & - & - \\
\hline Day 12 & $16.9^{b}$ & $20.2^{a}$ & $18.7^{\mathrm{a}}$ & $18.9^{a}$ & 1.08 & 0.02 & - & - \\
\hline Day 22 & $22.3^{c}$ & $27.3^{a}$ & $24.3^{b c}$ & $26.7^{\mathrm{ab}}$ & 1.08 & 0.01 & - & - \\
\hline Day 32 & $28.7^{b}$ & $35.3^{a}$ & $31.2^{\mathrm{b}}$ & $36.3^{\mathrm{a}}$ & 1.08 & 0.03 & - & - \\
\hline Day 42 & $36.1^{c}$ & $44.8^{a}$ & $39.5^{b}$ & $43.6^{a}$ & 1.08 & 0.03 & - & - \\
\hline Average serum glucose (mmol/L) & 5.2 & 6.2 & 5.6 & 5.1 & 0.41 & 0.09 & 0.01 & 0.21 \\
\hline Average body temperature $\left({ }^{\circ} \mathrm{C}\right)$ & 38.7 & 38.5 & 38.4 & 38.5 & 0.08 & 0.39 & 0.62 & 0.51 \\
\hline Average diarrhoea days & 7 & 4 & 3 & 4 & 1.11 & 0.41 & - & - \\
\hline Diarrhoea frequency & 2 & 1.1 & 1.1 & 1.0 & 0.30 & 0.07 & - & - \\
\hline Days fed electrolytes & 5 & 3 & 2 & 3 & 0.83 & 0.72 & - & - \\
\hline Faecal score & $2.3^{a}$ & $2.2^{\mathrm{ab}}$ & $2.1^{\mathrm{b}}$ & $2.1^{\mathrm{b}}$ & 0.03 & 0.04 & 0.52 & 0.63 \\
\hline
\end{tabular}

a,b,c means with the same superscripts across the row do not different at $(P<0.05)$. C: control, GA: 5 g: garlic, PB: 4 g: probiotics, GP: 5 g: garlic + 4 g: PB, IgG: immunoglobulin G; SEM: standard error of means

The GA, PB, and GP treatments did not affect feed, milk and water intakes in the current study. Nonetheless, the effects of garlic on DMI have been variable, with some authors reporting no effect on DMI (Khalelisizadeh et al., 2011; Wanapat et al., 2008) and others reporting improved DMI (Ahmed et al., 2009; Hassan et al., 2013). Similarly for PB group, Masucci et al. (2011) reported no effects on DMI while Di 
Francia et al. (2007) observed improved feed intake and general performance. The disparity responses with feed additives on DMI have been attributed to the quality, dosage and mode of preparation for GA (Lu et al., 2010) and species of microorganisms and their number in the PB products (Uyeno et al., 2015). The observed tendency to increase both DMI and water intake in GP-supplemented calves confirmed a positive correlation, as reported by Soltan (2009). Nocek et al. (2003) hypothesized that the effects of garlic were similar to those of probiotics in terms of the balanced gut microbial populations and the subsequent overall digestive stimulant action. Overall digestive stimulant action signifies the balance on microbial populations and their ability to enhance the activity of pancreatic lipase (Rao et al., 2003).

In the present study, final bodyweight did not respond to GA, PB, and GP treatments. This could be owing to the unaffected DMI that was observed in treated calves. Moreover, all calves from the present study had lower daily gain and feed intake than the breed standard for Holstein calves (Akayezu et al., 1994). The low feed intake and lower BW gain throughout the trial could be attributed to low birth weight of the calves used in this trial. The average BW $(36.2 \mathrm{~kg})$ of the calves in the present study was $5-7 \mathrm{~kg}$ lower than the breed standard of Holstein (42.76 kg) (Aksakal \& Bayram, 2009). It is well known that lighter birth weight decreases capability for adaptation to solid feed, resulting in increased morbidity because of disease (Morrill et al., 1995). Nonetheless, the effects of $P$ in calves have been associated with increased feed efficiency and weight gain (Lesmeister \& Heinrichs, 2005; Timmerman et al., 2005).

Serum IgG levels increased with age in all calves in agreement with a previous report (Athanasiadou \& Kyriazakis, 2004), although the noticeable IgG surge was in calves that received garlic-supplemented diets ( $G$ and GP). These results indicate that garlic-fed calves were in a healthier state than control calves. The increased effect of garlic supplementation on serum IgG was because of antioxidants such as alliin. Alliin modulates and regulates the early activation steps in immune development (Arreola et al., 2015) and enhances stimulation of B-cells and the secretion of interleukin (Washiya et al., 2013). The commonly recognized characteristic of $B$ cells is their ability to produce antibodies (LeBien \& Tedder, 2008). B cells are required for optimal $\mathrm{T}$ cell activation to certain antigens including low dose foreign proteins, pathogen challenge, and auto-antigens. Furthermore, their presence facilitates the genesis of the immune system, and maintains its integrity (Bouaziz et al., 2007). High serum IgG was observed in supplemented calves at each sampling, except on day 23 for PB. Probiotics are reported to act as adjuvants to the immune system and therefore stimulate IgG production (Naqid et al., 2015). However, reports on the effects of $P$ on immunity have been equivocal. Likewise, Athanasiadou and Kyriazakis (2004) and Naqid et al. (2015) reported increased serum IgG levels, while Masucci et al. (2011) observed no effects in calves' immune-status with PB supplementation. From these studies, the authors believe the discrepancies were because of varying concentrations of microbes, which determine the intensiveness of stimulus for immune cells, which affected the levels of circulating IgG. The unaffected serum glucose levels that were observed were within the recommended ranges (5.1 to $6.2 \mathrm{mmol} / \mathrm{L}$ ) (Al-Saiady, 2010; Meyer et al., 2009).

Reduced faecal score with P supplementation concurs with previous reports (Görgülü, 2003) and is attributed to antimicrobial-like compounds that are believed to act against gut pathogens (Roodposhti \& Dabiri, 2012). Surprisingly, garlic supplementation exhibited minimal effects on faecal score amid numerous reports about its anti-bacterial properties against Escherichia coli and Salmonella species (Ahmed et al., 2009) and inhibitory effects on coliform (Nikolic et al., 2004). From this, it is clear that the daily supplementation of garlic at $5 \mathrm{~g}$ that was used in the current study did not supply sufficient active alliin compound. In the study of Lu et al. (2011), the inhibition from garlic powder extracts was proportional to the concentration of the organosulfur compounds, suggesting that the antimicrobial effect was dependent on the number of sulfur atoms in the diallyl sulphides (alliin). This verified that organosulfur compounds (diallyl sulfides and thiosulfinates) contributed most to the antimicrobial effect of garlic, substantially more than phenolic compounds. The significant decrease of faecal score in calves fed GP could be explained by the synergic effects of garlic and probiotics. This combination could be beneficial to pre-weaned calves for diarrhoeal treatment, because lactic acid bacteria (Lactobacillus species as major bacteria of the probiotics) are microorganisms that are resistant to the inhibitory effects of garlic (Rees et al., 1993). In an in vitro study, supplementation with garlic powder induced the growth of Lactobacillus bacterial species in the gut and thus modulated gut microbiota (Filocamo et al., 2015).

\section{Conclusion}

Supplementation of garlic powder alone and in combination with probiotics improved serum IgG, showing potential to improve calf health. Additionally, higher serum $\lg G$ in GP revealed recommendable synergistic effects on the utilization of nutrients responsible for immunity modulation and regulation. Feeding a combination of garlic powder and probiotics increased immunity and reduced faecal score in dairy calves. 


\section{Acknowledgements}

Agricultural Research Council-Animal Production (ARC-AP) and University of Venda are gratefully acknowledged for supporting this research study.

\section{Authors' Contributions}

WTK, CMM and JJB contributed to the idea, design and study execution. FVN-C and CMM helped in starter feed, milk composition and statistical analysis. All co-authors participated in interpretation of the results of the study and construction of the manuscript.

\section{Conflict of Interest Declaration}

The authors declare that there is no conflict of interest and confirm that the manuscript has been read and approved by all the listed authors.

\section{References}

Ahmed, A.A., Bassuony, N.I., El-Habiab, S.A., Awad, S., Aiad, A.M. \& Mohamed, S.A., 2009. Adding natural juice of vegetables and fruitage to ruminant diets (b) nutrients utilization, microbial safety and immunity, effect of diets supplemented with lemon, onion and garlic juice fed to growing buffalo calves. World J. Agric. Sci. 5, 456-465.

Akayezu, J.M., Linn, J.Q., Otterby, D.E. \& Hansen, W.P., 1994. Evaluation of calf starters containing different amounts of crude protein for growth of Holstein calves. J. Dairy Sci. 77, 1882-1889. https://doi.org/10.3168/jds.S00220302(94)77130-7

Al-Saiady, M.Y., 2010. Effect of probiotic bacteria on immunoglobulin G concentration and other blood components of new born calves. J. Anim. Vet. Adv. 9, 604-609. DOI: 10.3923/javaa.2010.604.609

Aksakal, V. \& Bayram, B., 2009. Estimates of genetic and phenotypic parameters for the birth weight of calves of Holstein Friesian cattle reared organically. J. Anim. Vet. Adv. 8, 568-572. http://medwelljournals.com/abstract/?doi=javaa.2009.568.572

Amagase, H., Petesch, B.L., Matsuura, H., Kasuga, S. \& Itakura, Y., 2001. Intake of garlic and its bioactive components. J. Nutr. 131 (Supplement). 955-962

Arreola, R., Becerril-Villanueva, E., Cruz-Fuentes, C., Velasco-Velázquez, M.A., Garcés-Alvarez, M.E., HurtadoAlvarado, G., Quintero-Fabian, S. \& Pavón L., 2015. Immunomodulatory effects mediated by serotonin. J. Immun. Res. 2015. http://dx.doi.org/10.1155/2015/354957

Athanasiadou, S. \& Kyriazakis, I., 2004. Plant secondary metabolites: Antiparasitic effects and their role in ruminant production systems. Proc. Nutr. Soc. 63, 631-639. https://doi.org/10.1079/PNS2004396

Bouaziz, J.D., Yanaba, K., Venturi, G.M., Wang, Y., Tisch, R.M. \& Poe, J.C., 2007. Therapeutic B cell depletion impairs adaptive and autoreactive CD4+ T cell activation in mice. Proc. Natl. Acad. Sci. USA. 104, $20878-83$. DOI:10.1073/pnas.0709205105

Busquet, M., Calsamiglia, S., Ferret, A., Carro M.D. \& Kamel, C., 2005. Effect of garlic oil and four of its compounds on rumen microbial fermentation. J. Dairy Sci. 88, 4393-4404. https://doi.org/10.3168/jds.S0022-0302(05)73126-X

Calsamiglia, M., Busquet, P.W., Cardozo, Castillejo L., Ferret, A. \& Fandino, I., 2000. The use of essential oils in ruminants as modifiers of rumen microbial fermentation. Penn State Dairy Cattle Nutrition Workshop 87-101.

Church, D.C., 1976. Digestive physiology and nutrition of ruminants. Dig. Phys. O\&B books, Inc, Corvallis, OR, 2, 17-25. https://www.jstor.org/stable/3799218

Di Francia, A., De Rosa, G., Masucci, F., Romano, R., Borriello, I. \& Grassi C., 2007. Effect of Pisum sativum as protein supplement on buffalo milk production. Ital. J. Anim. Sci. 6, 472-475. https://doi.org/10.4081/ijas.2007.s2.472

Drackley, J.K., Baily, K.L., Bartlett, K.S. \& Blome, R.M., 2004. Supplementation of 1\% L-glutamine to milk replacer does not overcome the growth depression in calves caused by soy protein concentrate. J. Dairy Sci. 89(5),1688-1693. https://doi.org/10.3168/jds.S0022-0302(06)72236-6

Earley, B. \& Fallon, J.R., 1999. Calf health and immunity. Series No. 17. Grange Research Centre, Dunsany, Ireland. http://hdl.handle.net/11019/1431

Filocamo, A., Nueno-Palop, C., Bisignano, C., Mandalari, G. \& Narbad, A., 2015. Effect of garlic powder on the growth of commensal bacteria from the gastrointestinal tract. Phytomedicine 19, 707-11. DOI: 10.1016/j.phymed.2012.02.018

Ghosh, S., Mehla, R.K., Sirohi, S.K. \& Biswajit, R., 2010. The effect of dietary garlic supplementation on body weight gain, feed intake, feed conversion efficiency, faecal score, faecal coliform count and feeding cost in crossbred dairy calves. Trop. Anim. Health Prod. 42, 961-968. https://doi.org/10.1007/s11250-009-9514-5

Godden, S., 2008. Colostrum management for dairy calves. Vet. Clin. North Am. Food Anim. Pract. 24, $19-39$. https://doi.org/10.1016/j.cvfa.2007.10.005

Görgülü, M., Siuta, A., Öngel, E., Yurtseven, S. \& Kutlu, R. H., 2003. Effect of probiotic on growing performance and health of calves. Pak. J. Biol. Sci. 6, 651-654. https://doi.org/10.3923/pjbs.2003.651.654

Hassan, E.H. \& Abde-Raheem, S.M., 2013. Response of growing buffalo calves to dietary supplementation of caraway and garlic as natural additives. World Appl. Sci. J. 22, 408-413. DOI: 10.5829/idosi.wasj.2013.22.03.7363

Kekana, T.W., Marume, U., Muya, C.M. \& Nherera-Chokuda, F.V., 2019. Lactation performance and blood metabolites in lactating dairy cows micro-supplemented with Moringa oleifera leaf meal. S. Afr. J. Anim. Sci. 49, 709-716. http://dx.doi.org/10.4314/sajas.v49i4.12 
Khalelisizadeh, A., Vakili, A., Mesgaran, M.D. \& Valizadeh, R. 2011. The effects of garlic oil (Allium sativa), turmeric powder (Curcuma longa Linn) and monensin on total apparent digestibility of nutrients in Baloochi lambs. Intern. J. Anim. Vet. Sci. 5(11), 791-793. http://publications.waset.org/15917/pdf

Larson, L.L., Owen, E.G., Albright, J.L., Appleman, R.D., Lamb, R.C. \& Muller L.D., 1977. Guidelines towards more uniformity in measuring and reporting calf experimental data. J. Dairy Sci. 60, 989-991. https://doi.org/10.3168/jds.S0022-0302(77)83975-1

Lawrence, T.L.J. \& Pierce, J., 1983. Effect of certain variables on the performance of early-weaned calves. Anim. Prod. 36, 393-394. https://doi.org/10.1017/S000335610002585X

Lawson, L.D., 1996. The composition and chemistry of garlic cloves and processed garlic. In H.P. Koch \& L.D. Lawson (ed.). Garlic. The science and therapeutic application of Allium sativum L. and related species. Williams \& Wilkins, Baltimore, Md. https://ci.nii.ac.jp/naid/10027533860/ pp. 37-107

LeBien, T.W. \& Tedder, T.F., 2008. B lymphocytes: how they develop and function. Blood 112, 15701580. DOl:10.1182/blood-2008-02-078071

Lesmeister, K.E. \& Heinrichs, A.J., 2005. Effects of adding extra molasses to a texturized calf starter on rumen development, growth characteristics, and blood parameters in neonatal dairy calves. J. Dairy Sci. 88, 411-418. https://doi.org/10.3168/jds.S0022-0302(05)72702-8

Lu, X., Rasco, B.A., Jabal, J.M.F., Aston, D.E., Lin, M. \& Konkel, M.E., 2011. Investigating antibacterial effects of garlic (Allium sativum) concentrate and garlic-derived organosulfur compounds on campylobacter jejuni by using Fourier transform infrared spectroscopy, Raman spectroscopy, and electron microscopy. Applied \& Environmental Microbiology 77, 5257-5269. DOI: 10.1128/AEM.02845-10

Masucci, F., De Rosa, G., Grasso, F., Napolitano, F., Esposito, G. \& Di Francia, A., 2011. Performance and immune response of buffalo calves supplemented with probiotic. Livest. Sci. 137, $24-30$. https://doi.org/10.1016/j.livsci.2010.09.019

Meyer, N.F., Erickson, G.E., Klopfenstein, T.J., Greenquist, M.A., Williams, P. \& Losa, R., 2009. Effect of Crina Ruminants AF, a mixture of essential oil compounds on finishing beef steer performance. Nebraska Beef Cattle Reports. https://digitalcommons.unl.edu/animalscinbcr/80

Morrill, J.L., Morrill, J.M., Feyer herm, A.M. \& Lester, J.F., 1995. Plasma proteins and a probiotic as ingredients in milk replacer. J. Dairy Sci. 78, 902-907. DOI:10.3168/jds.S00220302(95)76704-2

Morrill, K.M. \& Howard, T.D., 2012. Two methods to determine IgG concentration in calf serum. Anim. Ind. Report 658, 40. https://doi.org/10.31274/ans_air-180814-722.

Naqid, I.A., Owen, J.P., Maddison, B.C.., Gardner, D.S., Foster, N., Tchórzewska, M.A. \& Gough, K.C. 2015. Prebiotic and probiotic agents enhance antibody-based immune responses to Salmonella typhimurium infection in pigs. Anim. Feed Sci. Tech. 201, 57-65. https://doi.org/10.1016/j.anifeedsci.2014.12.005

Nikolic, V.D., Stankovic, M.Z., Nikolic, L.B., Cvetkovic, D.M. \& Skala, D.U., 2004. Antimicrobial effect of raw garlic (Allium sativum L.) extracts, garlic powder and oil and commercial antibiotics on pathogen. Hemij. Indust. 58, 109-113. DOI: 10.3168/jds.S0022-0302(03)73610-8

Nocek, J.E., Kautz, W.P., Leedle, J.A.Z. \& Block, E., 2003. Direct-fed microbial supplementation on the performance of dairy cattle during the transition period. J. Dairy Sci. 86, 331-335.

Novak, K.N., Davis, E., Wehnes, C.A., Shields, D.R., Coalson, J.A., Smith, A.H. \& Rehberger, T.G., 2012. Effect of supplementation with an electrolyte containing a Bacillus-based direct-fed microbial on immune development in dairy calves. Res. Vet. Sci. 92, 427-434. DOI: 10.1016/j.rvsc.2011.04.008

O'Gara, E.A., Hill, D.J. \& Maslin, D.J.,2000. Activities of garlic oil, garlic powder, and their diallyl constituents against Helicobacter pylori. Appl. Environ. Microbiol. 66, 2269-2273. DOI: 10.1128/aem.66.5.2269-2273.2000

Piccone, G., Casell, S., Gianntto, C., Irene, V., Niutta, P. \& Giudice, E., 2009. Influence of age on profile of serum proteins in the calf. Acta Vet. 59, 413-422. https://doi.org/10.2298/avb0904413p

Rao, G., Pedone, C.A., Del Valle, L., Reiss, K., Holland, E.C. \& Fults, D.W., 2003. Sonic hedgehog and insulin-like growth factor signalling synergize to induce medulloblastoma formation from nestin-expressing neural progenitors in mice. Oncogene 23, 6156. https://www.nature.com/articles/1207818

Rees, L.P., Minney, S.F., Plummer, N.T., Slater, J.H. \& Skyrme, D.A., 1993. A quantitative assessment of the antimicrobial activity of garlic (Allium sativum). World J. Microbiol. Biotechnol. 9. 303-307. DOI: 10.1007/BF00383068.

Roodposhti, P.M. \& Dabiri, N., 2012. Effects of probiotic and prebiotic on average daily gain, faecal shedding of Escherichia coli, and immune system status in new-born female calves Asian-Australas. J. Anim. Sci. 25, 1255. DOI: 10.5713/ajas.2011.11312

Rumsey, T.S., Kahl, S. \& Elsasser, T.H., 1999. Field method for monitoring blood glucose in beef cattle. J. Anim. Sci. 77, 2194-2200

SAS Institute Inc. SAS/STAT® User's Guide, Cary, NC: SAS Institute Inc. Version 9. 2, 2008

Seifzadeh, S., Mirzaei Aghjehgheshlagh, F., Abdibenemar, H., Seifdavati, J. \& Navidshad, B., 2017. The effects of a medical plant mix and probiotic on performance and health status of suckling Holstein calves. Ital. J. Anim. Sci.16, 44-51. https://doi.org/10.1080/1828051x.2016.1249421

Soltan, M.A., 2009. Effect of essential oils supplementation on growth performance, nutrient digestibility, health condition of Holstein male calves during pre- and post-weaning periods. Pak. J. Nutr. 8 642-652. DOI: 10.3923/pjn.2009.642.652

Timmerman, H.M., Mulder, L., Everts, H., Van Espen, E., Van Der Wal, D.C., Klaassen, G., Rouwers, S.M., Hartemink, R., Rombouts, F.M. \& Beynen, A.C., 2005. Health and growth of veal calves fed milk replacers with or without probiotics. J. Dairy Sci. 88, 2154-2165. https://doi.org/10.3168/jds.S0022-0302(05)72891-5 
Ugur, F., 2005. Relationships between body measurement of dairy calves at six months of age and age at first calving and milk production. J. Cent. Europ. Agr. 6, 191-194. https://hrcak.srce.hr/16855

Uyeno, Y., Shigemori, S. \& Shimasato, T., 2015. Effect of probiotics/prebiotics on cattle health and productivity. Microbes Environ. 30, 126-132. DOI: 10.1264/jsme2.ME14176

Wanapat M., Khejornsart, P., Pakdee P. \& Wanapat S., 2008. Effect of supplementation of garlic powder on rumen ecology and digestibility of nutrients in ruminants. J. Sci. Food Agric. 88, $2231-2237$. https://doi.org/10.1002/jsfa.3333

Washiya, Y., Nishikawa, T. \& Fujino, T., 2013. Enhancement of intestinal IgA production by ajoene in mice. Biosci. Biotechnol. Biochem. 77, 2298-2301. https://doi.org/10.1271/bbb.130408

Zhang, R., Zhou, M., Tu, Y., Zhang, N.F., Deng, K.D., Ma, T. \& Diao, Q.Y., 2016. Effect of oral administration of probiotics on growth performance, apparent nutrient digestibility and stress-related indicators in Holstein calves. J. Anim. Physio. Anim. Nutri. 100, 33-38. https://doi.org/10.1111/jpn.12338

Zhong, R., Xiang, H., Cheng, L., Zhao, C., Wang, F., Zhao, X. \& Fang, Y., 2019. Effects of feeding garlic powder on growth performance, rumen fermentation, and the health status of lambs infected by gastrointestinal nematodes. Animals 9, 102. DOI: 10.3390/ani9030102 